\title{
Interrelationships of emotional intelligence with the awareness of request and apology strategies in an EFL setting
}

\author{
Zohreh Ghenaati and Ma'ssoumeh Bemani Naeini* \\ English Department, School of Foreign Languages,Mashhad Branch, Islamic Azad University, Ostad Yousefi, \\ Ghasemabad, PO Box 91735-413, Mashhad, Iran
}

\begin{abstract}
Taking the approach of interlanguage pragmatic analysis based on the theories of Speech Acts and Emotional Intelligence (EI), the main purpose of the present study was to find the interrelationships among components of EI, and awareness of request and apology strategies among Iranian TEFL students. The study was conducted on 200 English teaching majors from Mashhad universities. EI was measured through a translated form of Bar-On emotional quotient inventory and a self-developed questionnaire for measuring the apology and request strategies. The results of path analysis showed that among five sub-constructs of EI, four variables positively and significantly predict request strategies: Interpersonal $(\beta=.40, p<.05)$, Intrapersonal $(\beta=.16, p<.05)$, Adaptability $(\beta=.17, p<.05)$, and Stress management $(\beta=.15$, $\mathrm{p}<.05)$. Moreover, among five sub-constructs of EI, three variables of Interpersonal $(\beta=.16$, $\mathrm{p}<.05)$, Intrapersonal $(\beta=.22, \mathrm{p}<.05)$, and Stress management $(\beta=.12, \mathrm{p}<.05)$ are predictors of apology strategy. The results also indicate that the proposed model had perfect fit with the empirical data. Furthermore, the results of correlation showed that General Mood is positively and significantly correlated with apology and request. Thus, it is suggested that educators and policy makers consider the importance of EI in improving request and apology strategies.
\end{abstract}

Keywords: Apology strategies; emotional intelligence; request strategies

\begin{tabular}{|ccc|}
\hline First Received: & Revised: & Accepted: \\
22 December 2018 & 30 March 2019 & 3 May 2019 \\
Final Proof Received: & Published: \\
27 May 2019 & 31 May 2019 \\
\hline How to cite (in APA style): & \\
Bemani Naeini, M., \& Ghenati, Z. (2019). Interrelationships of emotional intelligence with the \\
awareness of request and apology strategies in an EFL setting. Indonesian Journal of \\
Applied Linguistics, 9, 148-156. doi: 10.17509/ijal.v9i1.14486 \\
\hline
\end{tabular}

\section{INTRODUCTION}

The realization of the conventions of social interactions has always been an issue for the foreign language speakers. Such awareness may be related to individual's cognitive abilities, such as Emotional intelligence (EI). It is believed that successful people are those who use a variety of their different intelligences including EI in their life. In fact, EI can assist people in all domains, whether in intimate relationships or in teamwork and social interactions. Thus, EI affects the quality of relationships (Goleman, 1995, 1998). In other words, emotionally intelligent people are able to identify certain types of behaviors and interactions. They are able to recognize and engage easily with one another and use emotions as a tool to better understand the others (Mayer, Roberts \& Barsade, 2008).

On the other hand, the role of pragmatic awareness, i.e. the knowledge and use of speech acts strategies, has been frequently emphasized (Leow, 1997, 2000; Schmidt, 1990; Takahashi, 2005). Austin (1962) defined speech acts as communicative actions which are performed through utterances. To him, "when we utter a sentence or a phrase, we are performing an act to which we expect our listeners to react with verbal or nonverbal behavior" (p. 65).

Among the list of speech acts, request and apology are used more frequently than other speech acts and are emphasized more for having a crucial role in successful

\footnotetext{
* Corresponding Author

Email: mbemani.2000@gmail.com
} 
communication. Both are involved in the issue of face threatening act in that during a request act, the hearer's negative face (i.e. the wish to be done) is threatened, because the speaker is showing dominance by requesting. If the hearer does not accept to do the request, the requester may lose his or her face. Further, apology, as an act of agreement to express regret or asking forgiveness for a mistake or offense, plays a crucial role in either keeping or losing the interlocutors' faces (Austin, 1962).

In the light of the awareness of such speech acts by $\mathrm{EF} / \mathrm{SL}$ learners for successful interactions on the one hand, and the important role EI plays in language learning, on the other hand, one can hypothesize that the former theoretical concept (in the domain of sociolinguistics) and the latter (in the area of cognitive psycho-linguistics) might be directly linked to one another. That is why this study seeks to investigate Goleman's (1995) view that being able to rein over emotional impulses, to read another's innermost feelings, and to handle relationships smoothly helps people express their speech acts like apology and request.

Individual difference research has a considerable history in applied linguistics. Among the important features accountable for individual differences in L2 learning, some are concerned with establishing "abilities (i.e., cognitive capabilities for language learning) and propensities (i.e., cognitive and affective qualities involving preparedness or orientation to language learning)" (Ellis, 2004, p. 530). So, in the lieu of language learning/learner ideology, individual differences can be discussed in the realms of psycholinguistics and sociolinguistics.

\section{Language learning in the realm of psycholinguistics}

In the realm of psycholinguistics, the issues of individual differences have gained the interest of scholars and educators studying language acquisition (e.g. Ellis, 2004; Gardner, 1983; Goleman, 1995). As for the role of cognitive abilities, intelligences come into play in education. As such, one of the main representations of individual cognitive differences is the concept of EI which is related to a more recent view about intelligence (Ellis, 2004); i.e. multiple intelligences which rose against the existence of "g", as one single construct. That is why educators have developed interest in studying the role of EI, as a closely related phenomenon which encompasses both aspects of cognition and affect.

The notion of EI has been established to contribute to the identification of learning potentiality in individuals and has been identified as an individualdifference variable that plays a function in determining success in several kinds of human performance and which can be improved to some extent (Van Rooy \& Viswesvaran, 2007). It refers to the effective incorporation of emotion and thought. It is mainly about the aptitude to reason effectively with emotions, and the capability of emotions to increase thinking (Mayer,
Salovey, \& Caruso, 2004). From the EI models presented so far, the present study takes the approach of self-report mixed model which, as once put by Mayer, Roberts, and Barsade (2008), does not regard EI to be a kind of intelligence, but as a general notion that comprises (among others) motivations, interpersonal and intrapersonal skills, responsiveness, personality features and health. This model uses self-report tools that assess the subjective insight of the contributors; the "Bar-On Emotional Quotient Inventory" — titled after its designer, Bar-On (2004) — is a generally used test for this model.

Notwithstanding the considerable amount of research studies carried out so far on the issue of EI and general education, some investigators (e.g. Ghosn, 2001; Mayer, Salovey, \& Caruso, 2000) have specified that only a relatively small number of studies have been done in association with the role of EI in the context of second / foreign language pedagogy. Also, according to Garett and Young (2009), the related concept of affect has long been hidden in the shadows of foreign language learning issues, where the primary focus has been solely on the development of knowledge and use of the target language. Such a need deserves even more attention when literature informs us about the vital role of emotions in the process of language learning.

\section{Language learning in the realm of sociolinguistics}

Another theoretical concept underpinning the present study is related to sociolinguistic theory. It seeks to describe "language use as a social phenomenon and, where possible, $[\ldots]$ attempts to establish causal links between language and society, pursuing the complementary question of what language contributes to making community possible and how communities shape their languages by using them" (Coulmas, 1997, p. 2). In respect to SLA, sociolinguistic approaches have concentrated on a variety of factors involved, ranging from the individual's mind and the language system to the social and communicational setting in which language acquisition occurs, trying to comprehend which role the social setting and social features have in the co-construction of both linguistic knowledge and identity (Zschomler, 2017).

It is in the lieu of sociolinguistic theory, then, that the notion of linguistic pragmatics has been scrutinized in this study. LoCastro (2003) defined second language pragmatics as "the study of speaker and hearer meaning created in their joint actions that include both linguistic and non-linguistic signals in the context of socioculturally organized activities" (p. 15). Accordingly, academic settings involve a great knowledge of pragmatics. In fact, "Asking questions and engaging in questioning progression in talk, symbolize an enveloping part of academic and work life that is serious for receiving ideas, information, contributing, and being actively involved in the environment" (Başturkmen, 2001, p. 4). In the same vein, in such settings, the desire for having a successful communication triggers the need, especially for second 
language learners to develop awareness about how to plan, arrange, and study the use of communicative strategies (Chang, 2009).

\section{Speech acts}

A good deal of such realization is encompassed in the theory of speech acts which aims at instructing language users how to use the language in order to establish successful communication. The theory "is concerned with the philosophy of language, i.e. how we accomplish actions with words (form-function); with the knowledge of the required underlying assumptions (conventional/nonconventional); and with the interpretations of acts through language" (Flowerdew, 2013).

Austin (1962) and Searle (1969) are recognized for developing the speech act theory which helps to shape our understanding about being more considerate of what is necessary for an effective and proper interaction. A speech act is not described as a sentence or an expression, but an act on its own right. As Austin (1962) maintains, language is more than making sentences of fact, it has a performative role to perform social actions. As an example, in stating, 'I apologize', the speaker performs both a linguistic and social role. With this in mind, Austin (1962) suggested that when creating expressions, a speaker really accomplishes three acts: the locutionary act (the expressions themselves), the illocutionary act (the speaker's purpose behind the words, like requesting or apologizing) and the perlocutionary act (the impact of the expression on the hearer). Among all, the illocutionary act is said to be the fundamental emphasis of speech act theory. The illocutionary act, also recognized as illocutionary force, presents a signal as to how the speaker needs the expression to be inferred, and is normally recognized by Illocutionary Force Indicating Devices (IFIDs) like performative verbs (e.g., requesting or apologizing), or word order and intonation (Barron, 2002).

In addition, Searle (1975) distinguished between two types of speech acts (direct and indirect speech acts). The direct speech acts represent a transparent relationship between form and function. However, indirect speech acts combine "a non-literal primary illocutionary act" and "a literal secondary illocutionary act" which together constitute "a performance of that illocutionary act". (pp.60-62, as cited in Hesam \& Bemani Naeini, 2017). Speech acts are frequently accomplished indirectly (Searle, 1975).

One of the most frequently attended speech acts by the theory of politeness is the speech act of request. Searle (1976) classifies "request" in the category of "directives. He claims that among the five speech act sorts (representatives, directives, commissives, expressives, and declarations), directives, i.e., "attempts by the speaker to get the hearer to do something", are the most commonly studied (Searle, 1976, p. 11).

In studying request strategies, the concept of "face" has always been the center of attention. Brown and Levinson (1987) defined the concept of face, which had been originally coined by Goffman in 1971, as 'the public self-image that every member wants to claim for himself" (p.61). To put it differently, face is the selfimage that represents every member's desire to be unrestricted and the want to be accepted in particular circumstances. There are positive face and negative face. Positive face is "the want of every member that his wants be desirable to at least some others" and negative face refers to "the want of every competent adult member that his actions be unimpeded by others" (Brown \& Levinson, 1978, p. 67). To them, positive/ negative politeness may be intrinsically face-threatening acts (FTAs); i.e. the acts which threaten addressees' face or may make them feel uncomfortable and embarrassed. They maintain that requests are facethreatening acts since they threaten the addressee's negative face. Positive politeness acts are direct whereas negative politeness strategies and apologies are indirect. Furthermore, a request is accomplished by the speaker to influence on the intentional behavior of the hearer for the advantage of the former only and at the cost of the latter (Alzeebaree \& Yavuz, 2017).

However, one should bear in mind the factual phenomenon of variation when it comes to the generalizability of the issue. As a matter of fact, some scholars, like Tang and Zhang (2009) have challenged the usability of one universal model for studying linguistic pragmatics across cultures. In their study, Tang and Zhang (2009) came to realize that due to different cultural protocols, variation exists between Mandarin Chinese and Australian English when using compliment responses. In the same lieu, Leech (2007) investigated if for studying linguistic politeness, such as speech acts of request and apology, well-established models like the one proposed by Brown and Levinson (1987), which has been criticized for its Western bias, can be used for cross-cultural studies. In respect to this, he has proposed the framework of General Strategy of Politeness (GSP) which concentrates on two constraints: "major" and "minor". To him, in a successful polite communication, "major constraints' generally lend high values to the addressee whereas "minor constraints" put low values on the speaker's side. He hypothesizes that GSP generally accounts for the communicative politeness being practiced in both Easter and Western languages. However, acknowledging the existence of social and linguistic variation in the East and the West, Leech (2007) states that GSP provides for studying such differences. Thus, he concludes that regardless of the differences of social and linguistic parameters between the East and the West, the two societies are alike in terms of linguistic politeness.

The other speech act which is the concern of the present study is the speech act of apology. Olshtain (1989, pp. 156-7) defines apology as "a speech act which is proposed to supply support for the hearer who was really or potentially mal affected by a violation". In an act of apology, the speaker is prepared to mortify himself/herself to the point that the apology becomes a face-saving act for the hearer and a face-threatening act for the speaker. 
Investigators have posited a number of comprehensive categorizations for the semantic formulae enclosed in taking action of apology. Most of such models construct on the significant work of Goffman (1971) who portrayed apologizing as 'remedial work' expressed by requests (begging utterances), accounts (excuses/explanations), and apologies. He has categorized apologies as either 'ritual', motivated by social habits, or 'substantive'; i.e. the wish to restore any damage or harm caused by the earlier action. Such taxonomy has since been customized and prolonged by a number of researchers (e.g. Blum-Kulka \& Olshtain, 1984; Fraser, 1981; Olshtain \& Cohen, 1983; Owen, 1983). In their models, these researches have illustrated and used a variety of strategies to be undertaken for suitable apology behaviors. The strategies of apology proposed by Olshtain and Cohen (1983) were utilized to examine the speech act of apology in the current study.

Thus, drawing on the underlying theories of this research study; i.e. humanistic psychology and the approach of learner-centeredness in the realm of educational psychology and linguistic pragmatics in the domain of socio-linguistics, the review of the related conceptual views suggests the existence of a rationale to link cognitive factors, such as EI to social behaviors like speech acts strategies in order to make a more successful use of the language. However, in spite of the growing attention to the aspects of socio- and psycholinguistics in the realm of language learning, there is scarcity of studies with the aim of finding a relation between these two main aspects of language. In fact, research studies on the association of EI and academic success have been accomplished by several researchers (e.g. Gates, 2000; Motallebzadeh \& Azizi, 2012; Nazir \& Masrur, 2010; Pishghadam, 2009; Qualter, Whiteley, Hutchinson, \& Pope, 2007), but there is scarcity of studies on the association of EI and the consciousness of request and apology strategies.

Hence, believing that the integration of elements of sociology and psychology may increase the effectiveness of L2 pedagogy, this study tries to find the relationships between Iranian English majors' EI and their awareness of request and apology to find out what aspects of the fore-mentioned dimensions are in interaction with one another. In doing so, the following questions are addressed: (1) what are the interrelationships among all components of Emotional Intelligence and the awareness of request and apology strategies among junior and senior English Majors from Mashhad Universities?; and (2) to what extent is the SEM model, proposed by this study, appropriate for an Iranian context of English-major BA students?

\section{METHOD}

\section{Respondents}

In this study, all junior and senior English majors from Mashhad universities were considered the target population. The sample size consisted of 225 students who were requested to sign a statement of consent beforehand. The sample selection procedure in this research study was that of purposeful convenience sampling, based on available samples who were reached out both online and through in-person procedure. The actual sample size, however, was 200 as determined based on the returned responses. The study sample group comprised both males $(n=53)$ and females $(n=147)$. The study was carried out on purposefully selected samples; i.e. junior and senior university students whose level of English was assumed to be high enough to have reliable realization of pragmatic aspects of English L2. The participants were expected to participate with full determination as they were assured that the collected data would remain confidential and the whole procedure was totally voluntary; i.e. they could opt out of the procedure at any time if for any reason they did not feel comfortable to continue. Also, as a means of encouragement, they were told to contact the researchers via the e-mail to find out about the results if they wished so.

\section{Instruments}

One of the instruments used in this study was a 5-ranked Bar-On Emotional Quotient Inventory (1997) including 117 items which were restructured in Persian and reduced to 90 items by Samouei (2003). The reason for adopting the Persian version was to avoid any potential ambiguity. There are five subscales intra-personal, interpersonal, adaptability, stress management and general mood. The fifteen components are emotional selfawareness, assertiveness, self-regard, self-actualization, independence, empathy, inter-personal interrelationship, social responsibility, problem solving, reality testing, flexibility, stress tolerance, impulse control, happiness, and optimism.

The second instrument was a self-developed multiple-choice questionnaire about the respondents' awareness of apology and request strategies in English. They were required to read the given situations and imagine themselves in those situations; then, choose one of the alternative responses which they thought would best fit as a linguistic reaction in terms of using the appropriate strategies for expressing apology and request in English L2. There are six situations designated to elicit apology strategies, and six to draw out request language use. In all twelve situations, social elements of distance, intimacy, and degree of imposition were considered.

The responses to the first six items about apology rank from 1 to 5, based on Olshtain and Cohen's (1983) Model, identifying five typical linguistic realizations (strategies), namely: an expression of an apology; an expression or account of the situation, an acknowledgement of responsibility; an offer of repair; and a promise of forbearance (as cited in Flowerdew, 2013).

For ranking the responses to the last six items about request strategies, Brown and Livingstone's (1987) taxonomy was adopted. Accordingly, the responses are ranked from 1 (on-record, bald, without 
regressive action) to 5 (don't do the FTA). As for the analysis of item reliability, the results of the reliability coefficient test for the instruments are summarized in Table 1, showing acceptable indexes of Cronbach alpha.

Table 1. The results of Cronbach Alpha for the instruments

\begin{tabular}{lcc}
\hline Scale & $\begin{array}{c}\text { Number of } \\
\text { items }\end{array}$ & $\begin{array}{c}\text { Cronbach } \\
\text { alpha }\end{array}$ \\
Emotional Intelligence & 90 & .79 \\
Request & 6 & .85 \\
Apology & 6 & .91 \\
\hline
\end{tabular}

\section{Procedures}

The procedure of data collection lasted for four months, starting from February 2018 till June 2018. The questionnaires were distributed among the participants, both through google.com by sending emails and inperson procedures. As for gathering the demographic information, the data were gathered in terms of the following: 1) age, 2) gender, 3) degree of education, and 4) English learning background. The respondents were asked to answer the questions confidently and honestly. They should have answered both of the questionnaires in about 25 minutes.

\section{Data analysis}

The research type of the current study was a quantitative survey with a correlational design. Three kinds of variables; i.e. EI, apology strategies, and request strategies and their sub-categories were to be correlated. The data were analyzed using Structural Equation Modeling (SEM). Based on the EI Theory and Speech Act Theory, emotionally intelligent people are able to identify certain types of behaviors, and certain interactions. They are able to recognize their own emotional states as well as the emotional states of the others'. They are able to engage easily with one another, and use emotions as a tool to better understand someone. On the other hand, there is a general agreement that language learners are more successful in their social interactions if they know how to use L2 speech acts strategies for expressing their requests and apologies (Eslami Rasekh, 1993; Searl, 1980). So, it can be hypothesized that a path can be created from all five components of EI to apology strategies, and one to request strategies. The second path shows bidirectional relationships between two types of strategies as both of them are supposed to be in interaction for a social behavior to be acceptable (Brown \& Levingston, 1987). Figure 1 presents the proposed model.

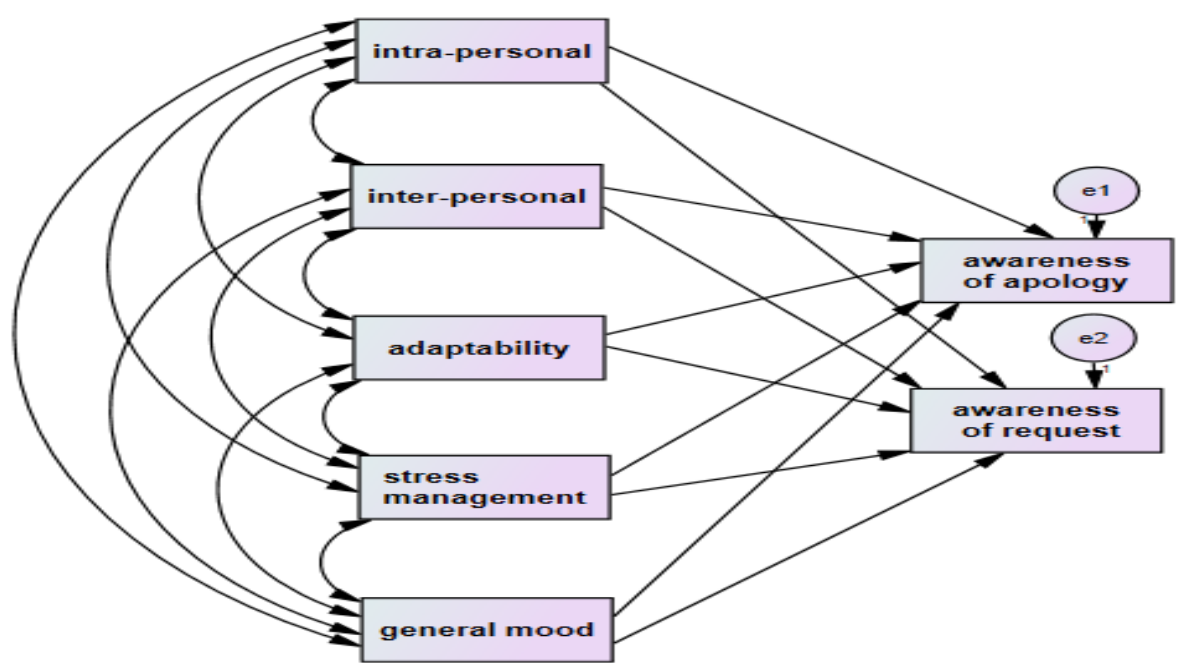

Figure 1. Proposed model of interrelationships among EI, request and apology strategies

\section{FINDINGS AND DISCUSSION}

Having tested the data for normality, the obtained sig value for all variables turned out to be higher than .05 $(\mathrm{EI}=0.07$; Request $=0.11 ;$ Apology $=0.09)$. Therefore, it could be safely concluded that the data was normally distributed across all the variables. Table 2 presents the descriptive statistics required as another assumption before conducting the main analysis.

Table 2. Descriptive statistics of the data

\begin{tabular}{lcccrc}
\hline & $\mathrm{N}$ & Minimum & Maximum & Mean & Std. Deviation \\
\hline Emotional Intelligence & 200 & 1.00 & 5.00 & 3.20 & .62 \\
Request & 200 & 13.00 & 30.00 & 23.92 & 4.55 \\
Apology & 200 & 11.00 & 30.00 & 21.73 & 4.99 \\
\hline
\end{tabular}

This study used path analysis to describe the directed dependencies among the variables. To examine the structural relations, the proposed model (Figure 1) was tested using Amos 24 statistical package. A number of fit indices were examined to evaluate the model fit: the Chi-square magnitude which shouldn't be significant, Chi-square/ $d f$ ratio which should be lower than 2 or 3 , the normed fit index (NFI), the good fit index (GFI), and the comparative fit index (CFI) with the cut value greater than .90 , and the Root Mean 
Square Error of Approximation (RMSEA) of about .06 or .07 (Schreiber, Stage, King, Nora, \& Barlow, 2006). Table 3 shows the goodness of fit indices before the modification.



Figure 2. Path analysis of the relationship between variables before modification

Table 3. Goodness of Fit Indices before modification

\begin{tabular}{lcrrrc}
\hline & X2/df & GFI & NFI & CFI & RMSEA \\
\hline Acceptable fit & $<3$ & $>.90$ & $>.90$ & $>.90$ & $<.08$ \\
Model & 3.09 & .91 & .87 & .86 & .09 \\
\hline
\end{tabular}

As demonstrated in Table 3, the data do not enjoy Goodness of Fit Indices. Therefore, the model needs some modification. In order to modify the model, three non-significant paths were removed: general mood to request $(\beta=.04, p>.05)$, general mood to apology $(\beta=$ $.02, \mathrm{p}>.05)$, and adaptability to apology $(\beta=.09, \mathrm{p}>.05)$. The modified model is presented in Figure 3 and Table 4 shows the goodness of fit indices after the modification.

As demonstrated in Table 4, the Chi-square/df ratio (2.95), RMSEA (.078), GFI (.92), NFI (.90) and CFI (.91), all the fit indices lie within the acceptable fit thresholds. Hence, it can be concluded that the proposed model had perfect fit with the empirical data after the modification.

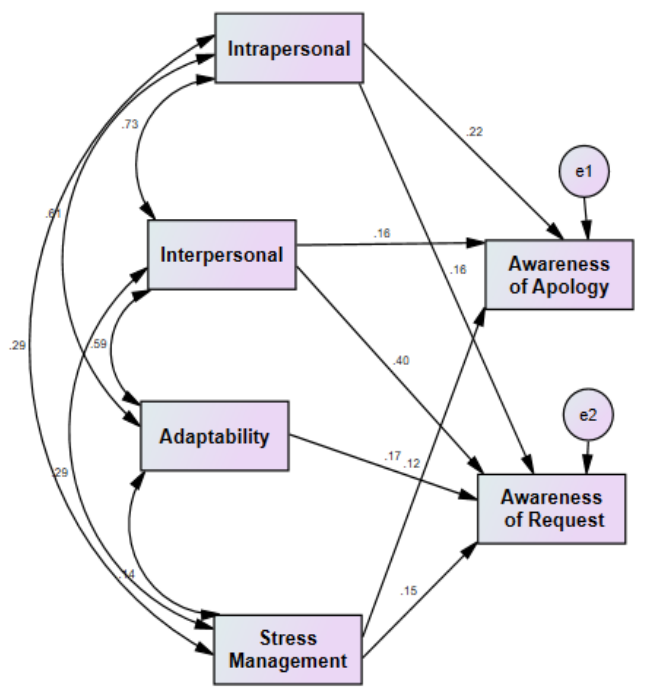

Figure .3 The model after modification

Table 4. Goodness of Fit Indices after modification

\begin{tabular}{llllll}
\hline & X2/df & GFI & NFI & CFI & RMSEA \\
\hline Acceptable fit & $<3$ & $>.90$ & $>.90$ & $>.90$ & $<.08$ \\
Model & 2.95 & .92 & .90 & .91 & .078 \\
\hline
\end{tabular}

As Figure 3 illustrates, among five sub-constructs of Emotional Intelligence, four variables predict request strategies positively and significantly: Interpersonal $(\beta=$ $.40, \mathrm{p}<.05)$, Intrapersonal $(\beta=.16, \mathrm{p}<.05)$, Adaptability $(\beta=.17, p<.05)$, and Stress management $(\beta=.15, p<.05)$. Moreover, among five sub-constructs of Emotional Intelligence, three variables predict apology strategies positively and significantly: Interpersonal $(\beta=.16$, $\mathrm{p}<.05)$, Intrapersonal $(\beta=.22, \quad \mathrm{p}<.05)$, and Stress management $(\beta=.12, p<.05)$. So, based on the statistic results, the null hypotheses formulated for this study are rejected.

In order to verify the results of SEM analysis regarding the relationships among the variables, Pearson correlation was employed. Table 5 presents the results of correlation.

Table 5. Results of correlation between EI, and the awareness of request and apology strategies

\begin{tabular}{|c|c|c|c|c|c|c|c|c|c|}
\hline & & 1 & 2 & 3 & 4 & 5 & 6 & 7 & 8 \\
\hline 1. & Interpersonal & 1.00 & & & & & & & \\
\hline 2. & Intrapersonal & $.75^{* *}$ & 1.00 & & & & & & \\
\hline 3. & Adaptability & $.63^{* *}$ & $.61^{* *}$ & 1.00 & & & & & \\
\hline 4. & Stress Management & $.33^{* *}$ & $.34^{* *}$ & $.20^{* * *}$ & 1.00 & & & & \\
\hline 5. & General Mood & $.47^{* *}$ & $.60^{* * *}$ & $.54^{* *}$ & $.36^{* *}$ & 1.00 & & & \\
\hline 6. & EQ & $.69^{* * *}$ & $.71^{* * *}$ & $.67^{* *}$ & $.58^{* * *}$ & $.62^{* *}$ & 1.00 & & \\
\hline 7. & Request & $.65^{* *}$ & $.59^{* * *}$ & $.52^{* *}$ & $.34^{* * *}$ & $.45^{* *}$ & $.68^{* *}$ & 1.00 & \\
\hline 8. & Apology & $.35^{* * *}$ & $.37^{* * *}$ & $.29^{* * *}$ & $.23^{* * *}$ & $.21^{* * *}$ & $.39^{* *}$ & $.49^{* *}$ & 1.00 \\
\hline
\end{tabular}

As shown in Table 5, request had the highest relationship with interpersonal $(r=.656, p<.05)$ and the lowest relationship with stress management $(r=.341$, $p<.05)$. In addition, apology was found to have the highest relationship with intrapersonal $(r=.358, \mathrm{p}<.05)$ and the lowest relationship with general $\operatorname{mood}(\mathrm{r}=.211$, $\mathrm{p}<.05)$.After comparing the results of Pearson correlation and path analysis it was found that although in path analysis, one of the five sub-constructs of EI (general mood) did not predict apology and request 
strategies, different results were found by correlational analysis. The results of correlation showed that General Mood is positively and significantly correlated with total apology and request strategies.

The results of path analysis indicated that the model of relationship between emotional intelligence, and the awareness of request and apology strategies had perfect fit with the empirical data after the modification. It means that this model can be used for further studies on the relationship between these constructs. Moreover, the results of path analysis showed that among five subconstructs of Emotional Intelligence, four subconstructs (Interpersonal, Intrapersonal, Adaptability, and Stress management) are positive predictors of request strategies. Among these predictors, Interpersonal is the strongest one predicting request strategies by $40 \%$. In other words, Emotional intelligence can impact the awareness of request strategies.

This is explainable by the fact that theoretically, EI is the ability to manage the emotions, and interpersonal EI is the ability to recognize one's own and other people's feelings for managing emotions in our relationships. EI has been closely related to the concept of social intelligence, with some viewing emotional intelligence as a sub-component of social intelligence in which understanding oneself and understanding others in interpersonal relationships can affect social relations such as request (e.g., Gardner, 1983; Guilford, 1967). Therefore, it seems natural that an individual, who has ability to manage his/her feelings in their relationships, is more apt to using request strategies in his/her speech. In other words, while requesting, people need to be interpersonally intelligent, having the ability to express their want so that they reduce the degree of FTA.

This finding is in line with Brown and Levinson's (1987) theory of politeness. One of the important components of Brown and Levinson's theory of politeness is the inclusion of interpersonal factors that are assumed to impact on language use. In addition, it is supported by Holtgraves and Yang (1992) who conducted a study to explore the effects of interpersonal variables on the use of request strategies. They concluded that interpersonal variables contributed significantly to request strategies. They maintain that studying the effect of interpersonal variables on politeness (especially request strategies) is an extremely important social psychological aspect of language use.

Furthermore, the results of path analysis revealed that among five sub-constructs of EI, three variables predict apology strategies positively and significantly: Interpersonal, Intrapersonal and Stress management. Among these predictors, Intrapersonal is the strongest one which predicts $22 \%$ of apology strategies. In other words, EI can impact on the awareness of apology strategies, too. Apology is defined as telling somebody that you are sorry for having done something that has created tribulations or sadness for them. In an apology, the speaker is prepared to mortify one's self to the point that the apology is a face-saving act for the hearer and a face-threatening act for the speaker (Brown \& Levinson, 1987). The results of this study revealed that individuals who have higher level of intrapersonal EI are better in terms of the awareness of apology strategies. Such a finding can be explained by the fact that Intrapersonal is something that exists within one person and intrapersonal EI is the ability to manage one's own personal emotions. A person with high intrapersonal EI knows himself well and is more capable of managing his feelings and motivating himself. Therefore, one can conclude that such individuals may find expressing apology as a relief, helping them out to get rid of the negative emotions involved.

Since apology is a face-threatening act for the speaker (Brown \& Levinson, 1987), doing this action is very difficult for a person who has low level of Intrapersonal EI. So, the opposite could also turn out to be true about those individuals who are identified with higher level of this component of EI. They may find it a face-saving act, indeed. To the researcher's best knowledge, there is no study yet to have explored the association between EI and apology strategies. Therefore, the results cannot be compared with others' studies.

\section{CONCLUSION}

This study aimed at extending the previous research on the awareness of request and apology strategies in the context of EFL learning by exploring the potential impact of EI. It can be concluded, then, that the null hypotheses were rejected by finding four components of EI (Interpersonal, Intrapersonal, Adaptability, and Stress management) as positive predictors of request strategies and three of them (Interpersonal, Intrapersonal, Stress management) as the predictors of apology strategies. Also, the results of path analysis indicated that the proposed model had perfect fit with the empirical data after modification and omitting three non-significant paths (general mood to request, general mood to apology, and adaptability to apology). So, it is possible to consider the results within the framework of Iranian English-major BA students.

The findings support earlier research (e.g., Gardner, 1983; Guilford, 1967) who view EI as being closely related to the concept of social intelligence. Considering EI as a sub-component of social intelligence, understanding oneself and understanding others in interpersonal relationships can affect social relations such as request. Therefore, the results seem logical in that those who have ability to manage their feelings in their relationships, are more apt to using request and apology strategies in their speech. The findings also support Brown and Levinson's (1987) theory of politeness. One of the important components of Brown and Levinson's theory of politeness is the inclusion of interpersonal factors that are assumed to impact on language use.

Consequently, the findings of this study contribute to EFL context in a sense that, as once pointed out by 
Goleman (1995), EI can be considered responsible for success in nearly every feature of person's life, including education as learners who are able to manage their emotions can focus for a long time and achieve educational attainment without any problem. To him, such learners are self-motivated, skillful and show strong personality traits. He considers EI as a set of vital skills for effective living and highlights the need for teaching its fundamentals in schools.

The results of this research study are hoped to be helpful for teachers to pinpoint the importance of EI and expressing emotion in improving awareness of request and apology strategies as they play crucial roles in social interactions. Accordingly, teachers can provide an intimate classroom atmosphere in which learners can easily express their feelings and improve their EI. To this end, students can express their own emotions and experiences during simulated social interactions using request and apology strategies. More particularly, in the context of L2 learning, educators have always emphasized the importance of communication for boosting the process of L2 learning. So, knowing that the awareness of speech acts is in direct relation to L2 success on the one hand, and finding a direct relationship between some of the components of EI and speech acts of request and apology, on the other, this study moves the body of pedagogical implications forward.

In addition, it was found that EFL learners who are more emotionally intelligent are also more aware of the ways to express their request and their apology more efficiently. So, such findings are more specifically helpful for EFL learners in that they can improve their L2 by working on ways to manage their emotions, whether they are of the type of interpersonal or intrapersonal.

Thus, the findings may provide a platform for other researchers to duplicate the present study and investigate more on these constructs. In order for the future studies to eliminate the limitations of the present study, the researchers suggest that they adopt a Mixed Methods Research approach to avoid relying on quantitative data, only. Also, it is acknowledged that the present study was limited to the data obtained from the BA students from some major universities in one city only. Further studies should be conducted by taking procedures that confirm a higher degree of randomization and, eventually, more generalizability. Furthermore, as the present study did not focus on students' performance, future researchers could also find out the connection among these constructs and students' performance by collecting spontaneous oral data. Finally, it is recommended that students' demographic information, such as their age, cultural and socioeconomic background be controlled, and their potential roles considered.

\section{REFERENCES}

Alzeebaree, Y., \& Yavuz, M. (2017). Realization of the speech acts of request and apology by Middle
Eastern EFL learners. Research in Science \& Technological Education, 13(11), 7313-7327. doi: 10.12973/ejmste/79603

Austin, J. L. (1962). How to do things with words. Oxford: Oxford University Press.

Bar-On, R. (1997). The Emotional Quotient Inventory (EQ-i): a test of emotional intelligence. Toronto: Multi-Health Systems.

Bar-On, R. (2004). Emotional quotient inventory: A measure of emotional intelligence. Canada: MultiHealth Systems Inc.

Barron, A. (2002). Acquisition in Interlanguage Pragmatics: Learning how to do things with words in a study abroad (Pragmatics \& beyond new series). Philadelphia, PA: John Benjamins Publishing Co.

Başturkmen, H. (2001). Descriptions of spoken language for higher level learners: the example of questioning. ELT Journal, 55(1), 4-13. doi: 10.1093/elt/55.1.4

Blum-Kulka, S., \& Olshtain, E. (1984). Requests and apologies: A cross cultural study of speech act realization patterns (CCSARP). Applied Linguistics, 5, 196-213. doi: 10.1093/applin/5.3.196

Brown, P., \& Levinson, S. (1987). Universals in language usage: Politeness phenomena. Cambridge: Cambridge University Press.

Chang, Y. F. (2009). How to say no: An analysis of cross-cultural difference and pragmatic transfer? Language Science, 31(4), 1-12.

Coulmas, F. (1997). The handbook of sociolinguistics. Oxford: Blackwell Publishing.

Ellis, R. (2004). Individual differences in second language learning. In A. Davies, \& C. Elder (Eds.), The handbook of applied linguistics (pp. 525-551). Oxford: Blackwell Publishing.

Eslami-Rasekh Z (1993) A cross-cultural comparison of the requestive speech act realization patterns in Persian and American English. In: L. F. Bouton \& Y. Kachru (eds), Pragmatics and Language Learning, monograph series (vol. 4 pp. 85-103). Urbana-Champaign: University of Illinois.

Flowerdew, J. (2013). Discourse in English Language Education. New York: Routledge.

Gardner, H. (1983). Frames of mind: The theory of multiple intelligences. New York: Basic Books.

Garrett, P., \& Young, R. (2009). Theorizing Affect in Foreign Language Learning: An Analysis of one Learner's Responses to a Communicative-Based Portuguese Course. The Modern Language Journal, 93, 209-226. doi: 10.1111/j.15404781.2009.00857.x

Gates, G. S. (2000). The socialization of feelings in undergraduate education: A study of emotional management. College Student Journal, 3(1), 1-12.

Ghosn, I. (2001). Nurturing emotional intelligence through literature. Forum, 39(1), 1-10.

Goffman, E. (1971). Relations in Public: Microstudies of the Public Order. London: Penguin. 
Goleman, D. (1995). Emotional Intelligence. New York, NY: Bantam Books.

Goleman, D. (1998). Working with Emotional Intelligence. New York, NY: Bantam Books.

Guilford, J. P. (1967). Creativity: Yesterday, Today and Tomorrow. Journal of Creative Behavior, 1(1), 314. https://doi.org/10.1002/j.21626057.1967.tb00002.x

Hesam, N., \& Bemani Naeini, M. (2017). A contrastive pragmatics study on the use of request strategies by Iranian EFL learners: A case of Persian L1English L2. International Journal of Language and Applied Linguistics, 3(1), 1-30.

Holtgraves, T., \& Yang, J. N. (1992). Interpersonal underpinnings of request strategies: General principles and differences due to culture and gender. Journal of Personality and Social Psychology, 62(2), 246-256 . doi: 10.1037/00223514.62.2.246

Leech, G. (2007). Politeness: Is there an East-West divide? Journal of Politeness Research, 3, 167206. doi: 10.1515/PR.2007.009

Leow, R. P. (1997). Attention, awareness, and foreign language behavior. Language Learning, 47(3)3558. doi: 10.1111/0023-8333.00017

Leow, R. P. (2000). A study of the role of awareness in foreign language behavior: Aware versus unaware learners. Studies in Second Language Acquisition, 22(4), 4557-4584.

LoCastro, V. (2003). An introduction to pragmatics: Social action for language teachers. United States: The University of Michigan Press.

Mayer, J. D., Roberts, R. D., \& Barsade, S. G. (2008). Human abilities: Emotional intelligence. Annual Review of Psychology, 59, 507-536. doi: 10.1146/annurev.psych.59.103006.093646

Mayer, J.D., Salovey, P., \& Caruso, D.R. (2000). Emotional intelligence as zeitgeist, as personality, and as a mental ability. In R. Bar-On and J.D.A. Parker (eds.), The handbook of emotional intelligence: Theory, development, assessment, and application at home, school, and in the workplace (pp. 92-117) San-Francisco, CA: Jossey-Bass.

Mayer, J.D., Salovey, P., \& Caruso, D.R. (2004). Emotional intelligence: theory, findings and implications. Psychological Inquiry, 60, 197-215.

Motallebzadeh, K., \& Azizi, V. (2012). The relationship between Iranian EFL learners' emotional intelligence and their performance on TOEFL/ PBT. International Journal of Linguistics, 4, 4655. doi: 10.5296/ijl.v4i1.1382

Nazir, M., \& Masrur, R. (2010). An exploration of emotional intelligence of the students of IIUI in relation to gender, age and academic achievements. Bulletin of Educational Research, 32(1), 37-51.

Olshtain, E. (1989). Apologies across cultures. In: Blum-Kulka, S., House, J., Kasper, G. (Eds.), Cross-cultural pragmatics: Requests and apologies. Norwood, NJ: Albex.

Olshtain, E., \& Cohen, A. (1983). Apology: A speech act set. In N. Wolfson and E. Judd (Eds.), Sociolinguistics and language acquisition (pp. 1836). Rowley, MA: Newbury House.

Owen, M. (1983). Apologies and remedial interchanges. A study of language use in social interaction. Berlin; New York; Amsterdam: Mouton.

Pishghadam, R. (2009). A quantitative analysis of the relationship between emotional intelligence and foreign language learning. Electronic Journal of Foreign Language Teaching, 6(1), 31-41.

Qualter, P., Whiteley, H.E., Hutchinson, J.M., \& Pope, D.J. (2007). Supporting the development of emotional intelligence competencies to ease the transition from primary to high school.

Educational Psychology in Practice, 23(1), pp. 7995. doi: 10.1080/02667360601154584

Samouei, R. (2003). Emotional intelligence test (Bar$O n$ "s EQ-I). Tehran: Sina Research Center of Behavioral Sciences.

Schmidt, R. W. (1990). The role of consciousness in second language learning. Applied Linguistics, 11(2), 129-158. doi: 10.1093/applin/11.2.129

Schreiber, J. B., Nora, A., Stage, F. K., Barlow, E. A., \& King, J. (2006). Reporting structural equation modeling and confirmatory factor analysis results: A review. Journal of Educational Research, 99, 323-338. https://doi.org/10.3200/JOER.99.6.323-338

Searle, J. R. (1969). Speech Acts: An essay in the philosophy of language. Cambridge: Cambridge University Press.

Searle, J. R. (1975). Speech acts and recent linguistics. Annals of the New York Academy of Sciencies, 263(1), 27-38. doi: 10.1111/j.17496632.1975.tb41567.x

Searle, J. R. (1976). A classification of illocutionary acts. Language in Society. 5(1), 1-23.

Searle, J. R. (1980) Minds, brains, and programs. Behavioral and Brain Sciences, 3(3), 417-457

Takahashi, S. (2005). Noticing in task performance and learning outcomes: A Qualitative analysis of instructional effects in interlanguage pragmatics. System, 33(3), 437-461. doi: $10.1016 /$ j.system.2005.06.006

Tang, C., \& Zhang, Q. (2009). A contrastive study of compliment responses among Australian English and Mandarin Chinese speakers. Journal of Pragmatics, 41(2), 325-345.

Van Rooy, D. L., \& Viswesvaran, C. (2007). Assessing emotional intelligence in adults: A review of the most popular measures. In R. Bar-On, J. G. Maree, \& M. Elias (Eds.), Educating people to be emotionally intelligent (pp. 259-72). Westport, CT.

Zschomler, S. (2017). How Does Sociolinguistic theory contribute to insights about second language learning: A comparative analysis of two empirical studies. Cambridge Open-Review Educational Research e-Journal, 4, 46-65. 